Journal of Telenursing (JOTING)

Volume 3, Nomor 1, Juni 2021

e-ISSN: 2684-8988

p-ISSN: 2684-8996

DOI: https://doi.org/10.31539/joting.v3i1.2154

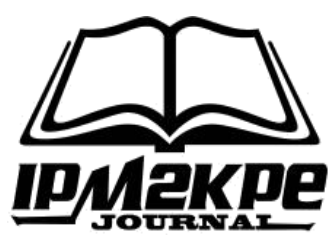

\title{
OPTIMALISASI PERAWAT SEHAT DALAM MEMBERIKAN PELAYANAN KEPERAWATAN BERMUTU
}

\author{
Endang Sudjiati ${ }^{1}$, Hanny Handiyani ${ }^{2}$, Krisna Yetti ${ }^{3}$, Cori Tri Suryani ${ }^{4}$ \\ Universitas Indonesia ${ }^{1,2,3}$ \\ RSUPN Dr. Cipto Mangunkusumo ${ }^{4}$ \\ endangsudjiati@yahoo.com ${ }^{1}$
}

\begin{abstract}
ABSTRAK
Penelitian ini bertujuan untuk mengembangkan panduan dan memberikan gambaran dalam mengupayakan optimalisasi kesehatan staf keperawatan di rumah sakit umum di Jakarta. Metode penelitian ini menggunakan pilot project mulai dari pengumpulan data, analisis masalah, penetapan prioritas masalah, penyusunan plan of action, implementasi dan evaluasi. Responden penelitian adalah kepala ruangan sebanyak 54 dan staf keperawatan sebanyak 479. Analisis masalah dilakukan dengan menggunakan diagram fishbone. Hasil analisis menunjukan bahwa ada masalah berupa belum optimalnya penerapan perilaku perawat sehat yang disebabkan belum adanya panduan perawat sehat, belum disusunnya SPO dan masih ada perawat yang belum mengetahui terkait dengan perilaku perawat sehat. Simpulan, solusi pemecahan masalah yaitu dengan membuat draft panduan perawat sehat di rumah sakit.
\end{abstract}

Kata Kunci: Optimalisasi Kesehatan, Panduan Perawat Sehat, Staf Keperawatan

\section{ABSTRACT}

This study aims to develop guidelines and provide an overview to optimize the health of nursing staff in public hospitals in Jakarta. This research method uses a pilot project starting from data collection, problem analysis, problem priority setting, preparation of a plan of action, implementation and evaluation. Research respondents were 54 room heads and 479 nursing staff. Problem analysis was performed using a fishbone diagram. The results of the analysis show that there is a problem in the form of not optimal adoption of healthy nurse behavior due to the absence of a guide for healthy nurses, the SPO has not been compiled and there are still nurses who do not know about the behavior of healthy nurses. In conclusion, the solution to the problem is to draft a guide for healthy nurses in the hospital.

Keywords: Health Optimization, Guidelines for Healthy Nurses, Nursing Staff

\section{PENDAHULUAN}

Rumah sakit perlu membuat kebijakan berupa panduan perawat sehat sebagai upaya optimalisasi kesehatan staf keperawatan di fasilitas pelayanan kesehatan. Panduan perawat sehat sebagai acuan dalam meningkatkan kesehatan staf keperawatan. Perilaku perawat yang kurang sehat saat bekerja adalah stres kerja, beban kerja yang tinggi, kurangnya waktu istirahat yang cukup, kerja shift, keyakinan budaya dan agama, masalah keuangan dan pengetahuan (Uchendu et al., 2020). Perawat dalam memberikan 
asuhan keperawatan sangat berisiko dengan pekerjaannya, namun banyak perawat tidak menyadari terhadap risiko pekerjaan tersebut. Perilaku perawat yang berhubungan dengan kesehatan adalah menciptakan lingkungan yang mempromosikan kesehatan, menjadi panutan, meningkatkan dukungan di tempat kerja, meningkatkan tingkat kepedulian, memberi contoh makanan sehat dan olahraga (Bak et al., 2020; Darch et al., 2019; Horton Dias \& Dawson, 2020).

Perawat sebagai individu berfokus pada memenuhi kebutuhan dasar, seperti cukup tidur, rutin aktivitas fisik dengan olahraga, makan makanan bergizi dan tetap menjaga hubungan baik dengan teman dan keluarga. Perawat harus mengetahui perasaannya, sehingga dapat mengenali gejala yang memburuk yaitu kesulitan tidur, merasa putus asa sehingga diperlukan dukungan dari rekan kerja, manajer atau profesional kesehatan lainnya (Croke, 2020). Perilaku aktivitas fisik bersifat multifaktorial, meliputi faktor sosial, lingkungan, psikologis dan genetik.

Panduan perawat sehat memiliki program aktivitas fisik yang rutin dilaksanakan. Penelitian menunjukkan bahwa orang yang aktif secara fisik dari semua kelompok umur dan etnis memiliki tingkat kebugaran kardiorespirasi, kesehatan dan kebugaran yang lebih tinggi dan risiko yang lebih rendah untuk mengembangkan beberapa penyakit medis kronis, termasuk penyakit kardiovaskular, dibandingkan dengan mereka yang tidak aktif secara fisik (Fletcher et al., 2018). Perawat yang bekerja 12 jam berturutturut menyebabkan gangguan waktu istirahat dan kepekaan fungsi otot terhadap pekerjaan keperawatan yang berdampak pada kelelahan fisik, sehingga diperlukan protokol pengujian kesehatan dengan pemeriksaan laboratorium dan penunjang lainnya (Thompson, 2019). Penelitian di Korea Selatan untuk meningkatkan kualitas praktik keperawatan, rumah sakit mempunyai peranan penting dalam membantu perawat mempertahankan gaya hidup sehat serta meningkatkan kondisi kerja mereka (Gartrell et al., 2020).

Kelebihan berat badan berdampak negatif terhadap prestasi kerja perawat. Selain hipertensi, sering teridentifikasi perawat mengalami rasa sakit pada daerah punggung dan terpajan tuberkulosis (TB). Penelitian (Woudberg et al., 2018; Wijaya \& Damayanti, 2018) terhadap perawat dan staf manajemen rumah sakit di rumah sakit umum di Western Cape Metropole, Afrika Selatan menemukan hasil penelitian bahwa perawat yang mendapat jadwal dinas malam sering teridentifikasi bertambahnya berat badan dan terjangkit Non Communicable Disease (NCD) atau dikenal dengan Penyakit Tidak Menular (PTM) seperti hipertensi penyakit utama terhadap masalah kesehatan. Untuk mencegah terjadinya kelebihan berat badan dan timbulnya penyakit akibat kerja yang tanpa disadari, diperlukan pengembangan panduan perawat sehat.

Perawat dituntut bekerja dengan memperhatikan risiko kecelakaan kerja dan menurunkan penyakit agar efektif dan efisien untuk meningkatkan produktivitas. Perawat sering kali menghadapi bahaya unik di tempat kerja yang dapat mempengaruhi kesehatan fisik, mental dan emosional (McNamara, 2020). Peran perawat berhubungan dengan lingkungan kerja, bukan hanya bertugas memberi asuhan keperawatan kepada pasien, akan tetapi memberi pendidikan kesehatan kepada pasien, keluarga, masyarakat dan lingkungannya. Sebagai pemberi asuhan keperawatan, perawat harus berfokus menjaga kesehatannya sendiri sebelum memberi kesehatan untuk orang lain. Diperlukan peran dan fungsi manajer keperawatan sebagai role model yang mampu memberi arahan kepada staf keperawatan untuk meningkatkan kesadaran dan pemahaman perawat tentang pentingnya menjaga kesehatan. 
Pengembangan panduan perawat sehat bertujuan untuk meningkatkan kesehatan staf keperawatan dalam memberikan asuhan keperawatan. Hal ini mendorong perawat untuk mempertimbangkan bagaimana pendekatan program kesehatan dapat tertanam dalam perannya untuk meningkatkan efektivitas asuhan keperawatan dengan memahami program kesehatan, identifikasi pendekatan program yang akan digunakan dalam latihan serta hambatan yang dialami dalam program kesehatan yang dilaksanakan (Phillips, 2019). Sejauh ini, penelitian sejenis mengenai pengembangan panduan tersebut belum pernah dilakukan. Oleh karena itu, peneliti tertarik untuk melakukan pengembangan panduan guna memberikan gambaran dalam mengupayakan optimalisasi kesehatan staf keperawatan di rumah sakit umum di Jakarta.

\section{METODE PENELITIAN}

Desain yang digunakan dalam penelitian ini adalah Pilot project serta analisis hasil dan gap implementasi dengan pembahasan berdasarkan literature review. Kegiatan yang dilakukan dalam Pilot project ini dimulai dari identifikasi masalah, dilanjutkan dengan analisis masalah, penetapan prioritas masalah, penyusunan plan of action, implementasi serta evaluasi. Ruang rawat yang digunakan dalam Pilot project ini adalah instalasi rawat inap terpadu, instalasi rawat jalan terpadu dan instalasi gawat darurat. Dasar pemilihan ruangan sebagai tempat pilot project adalah unit kerja yang mewakili pelayanan besar di RS X yang menggambarkan kompleksitas pelayanan yang diberikan.

Data dari Bidang Pelayanan Keperawatan RS X pada 15 Oktober 2020, menunjukan jumlah perawat manajer adalah 130. Adapun rincian dari perawat manajer sebagai berikut: 88 orang perawat manajer lini pertama (Kepala Ruangan), 25 orang perawat manajer lini tengah (Supervisor/Penanggung Jawab Keperawatan) dan 17 orang perawat manajer lini atas (Koordinator/Kepala Unit Kerja). Pengambilan data dilakukan melalui wawancara terstruktur, survei melalui kuesioner, observasi secara daring dan data sekunder yang didapat dari Bidang Pelayanan Keperawatan. Data tentang peran dan fungsi top manajer, diambil melalui wawancara terhadap Kepala Bidang Pelayanan Keperawatan dan Ketua Komite Keperawatan. Selain itu digunakan juga data sekunder dari Rencana Kerja Tahunan Bidang Keperawatan Tahun 2020.

Data mengenai peran dan fungsi kepala ruangan dikumpulkan dengan menggunakan metode survei melalui kuesioner, observasi lapangan melalui daring. Kuesioner diberikan kepada staf perawat (perawat pelaksana dan perawat primer) untuk mendapatkan gambaran tentang pelaksanaan peran dan fungsi kepala ruangan di unit kerjanya. Kuesioner juga diberikan kepada semua kepala ruangan untuk mendapatkan persepsi tentang kemampuan menjalankan peran dan fungsinya. Metode observasi lapangan melalui daring dilakukan untuk mengidentifikasi ketersediaan dan keterkinian dokumen dan pelaksanaan peran dan fungsi kepala ruangan di ruang kerjanya terkait panduan perawat sehat staf keperawatan.

\section{HASIL PENELITIAN}

Hasil wawancara dengan Ketua Komite Keperawatan menunjukkan bahwa salah satu persyaratan pengajuan kredensial adalah kondisi kesehatan perawat, apabila perawat tidak sehat, maka menjadi pertimbangan komite keperawatan untuk memberi rekomendasi atau tidak. Hasil wawancara dengan Kepala Bidang Pelayanan Keperawatan, saat ini belum ada panduan perawat sehat di RS X. Pengembangan panduan perawat sehat sangat diperlukan dan akan diusulkan dalam rencana kerja tahunan Bidang Pelayanan Keperawatan tahun 2021 dengan salah satu action plan 
adalah dilaksanakannya program perawat sehat bulanan. Bidang Pelayanan Keperawatan menyatakan membuat sosialisasi panduan perawat sehat pada staf keperawatan di rumah sakit $X$.

Hasil pengkajian awal staf keperawatan didapatkan bahwa persepsi staf keperawatan merasa kewalahan saat sedang melakukan asuhan keperawatan karena jumlah pasien yang terlalu banyak yang menjawab selalu $4.80 \%$, memahami tentang penyakit akibat kerja yaitu LBP/ HNP menjawab selalu $37.78 \%$, kekurangan staf keperawatan merupakan masalah umum di fasilitas kesehatan menjawab selalu 57.62, bekerja tidak sesuai dengan rasio perawat : pasien, akan menimbulkan kelelahan yang berdampak pada kualitas mutu keperawatan menjawab selalu 45.51\%, kualitas pekerjaan ditentukan oleh status kesehatan yang berdampak pada produktivitas saat memberikan asuhan keperawatan menjawab selalu 45.30\%, menjaga kesehatan dengan rutin berolahraga dan menjalani pola makan yang sehat menjawab selalu $24.63 \%$.

Fungsi kepala ruangan terkait dengan persepsi kepala ruangan dalam membuat perencanaan ketenagaan yang menjawab selalu $46.30 \%$, membuat jadwal dinas staf keperawatan sesuai kebutuhan pelayanan di ruangan, yang menjawab selalu $85.19 \%$, memberi orientasi staf baru dan peserta didik menjawab selalu 70.37\%. Berdasarkan analisis dari kepala ruangan didapatkan: $46.30 \%$ menjawab selalu dalam membuat perencanaan ketenagaan, membuat jadwal dinas staf keperawatan sesuai kebutuhan pelayanan di ruangan, menjawab selalu $85.19 \%$ dan pemberian orientasi staf baru dan peserta didik di ruangan, menjawab selalu $70.37 \%$.

Pemahaman kepala ruangan terkait fungsi pengarahan didapatkan: kepala ruangan membuat struktur organisasi menjawab selalu 35.19\%, menetapkan uraian tugas staf sesuai level kompetensi menjawab selalu 46.30\%, mengkoordinasikan kegiatan pelayanan dengan petugas lain yang berada di ruang rawat menjawab selalu $46.30 \%$. Analisis kepala ruangan memberi pujian kepada staf yang bekerja sesuai dengan SPO menjawab selalu $62.96 \%$, memberi teguran kepada staf perawat yang menyalahi aturan menjawab selalu $61.11 \%$, melakukan pendelegasian tugas sesuai SPO pada saat tidak berada di tempat menjawab selalu $66.67 \%$.

Identifikasi masalah menjadi dasar menentukan rencana tindakan penyelesaian. Penyelesaian masalah dengan membuat draft pengembangan panduan perawat sehat sebagai langkah awal optimalisasi kesehatan staf keperawatan di rumah sakit. Rangkaian kegiatan untuk penyelesaian masalah dibuat dalam bentuk Plan of Action (POA) dilakukan bersama Bidang Pelayanan Keperawatan dan Komite Keperawatan melalui brain storming dan diskusi terstruktur.

\section{Implementasi}

Hasil analisis fishbone menjadi dasar dalam menyusun rencana tindak lanjut menggunakan kerangka POSAC yaitu fungsi manajemen keperawatan mulai dari perencanaan, pengorganisasian, ketenagaan, pengarahan dan pengendalian/pengontrolan. Pada fungsi perencanaan, implementasi yang dilakukan adalah pengembangan panduan perawat sehat sebagai langkah awal optimalisasi kesehatan staf keperawatan di rumah sakit. Draft panduan disusun bersama Bidang Pelayanan Keperawatan dengan melibatkan Komite Keperawatan.

Implementasi fungsi pengorganisasian berupa usulan pembentukan time table penyusunan draft panduan perawat sehat. Adapun implementasi fungsi ketenagaan adalah usulan melibatkan anggota tim penyusunan draft panduan perawat sehat, Penanggung Jawab; Kepala Bidang Pelayanan Keperawatan, Ketua Komite 
Keperawatan; Kepala Seksi Rawat Inap, Anggota; Tim Penyusun draft panduan perawat sehat. Kepala Seksi Rawat Inap adalah manajer level atas yang merupakan pejabat struktural eselon IV di bawah Kepala Bidang Pelayanan Keperawatan yang bertanggung jawab dalam kesehatan staf keperawatan di rumah sakit. Tim penyusun draft panduan perawat sehat merupakan manajer yang memiliki kemampuan dalam memberikan masukan terkait program peningkatan kesehatan staf keperawatan. Implementasi pada fungsi pengarahan adalah konsultasi dengan pembimbing akademik dan pembimbing klinik untuk mendapat arahan dan bimbingan terkait draft pengembangan panduan perawat sehat. Implementasi fungsi pengendalian yaitu membuat usulan pembentukan tim untuk membantu mengawal program pengembangan panduan perawat sehat sebagai langkah optimalisasi kesehatan staf keperawatan.

\section{Evaluasi}

Hasil analisis mengenai masalah penerapan keselamatan dan kesehatan kerja menggunakan fishbone analysis dapat dilihat pada gambar berikut ini:

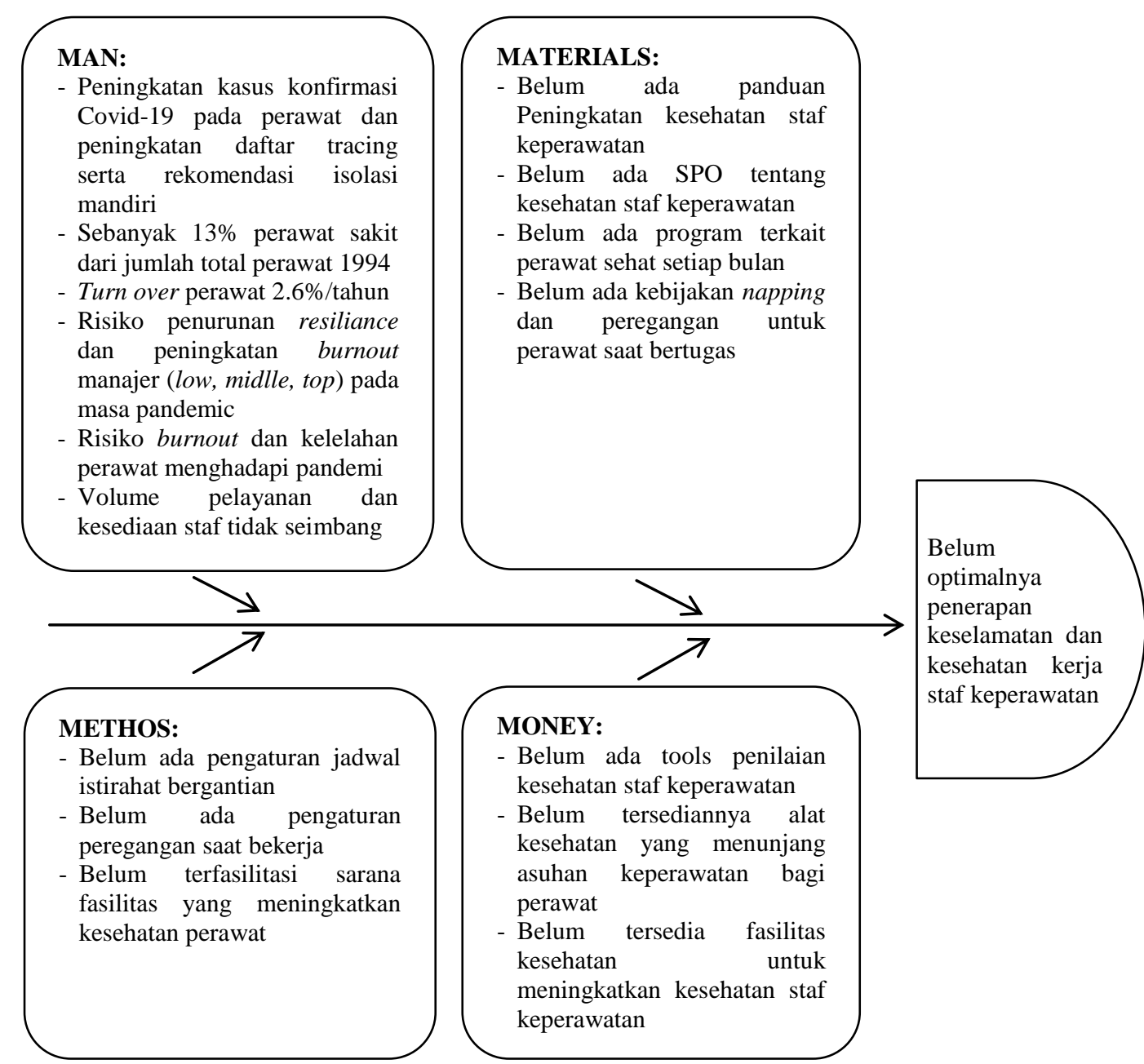

Gambar. 1

Analisis Masalah Penerapan Keselamatan dan Kesehatan Kerja Menggunakan Fishbone Analysis 
Hasil akhir program residensi adalah tersusunnya draft pengembangan panduan perawat sehat yang telah selesai dilaporkan ke pimpinan rumah sakit dan disosialisasikan kepada para perawat manajer di RS X di Jakarta yang akan dikoordinir oleh Bidang Pelayanan Keperawatan dan manuskrip dengan judul "Pengembangan Panduan Perawat Sehat dalam Upaya Optimalisasi Kesehatan Staf Keperawatan di Rumah Sakit X di Jakarta”.

\section{PEMBAHASAN}

Survei melalui kuesioner kepada kepala ruangan memperlihatkan bahwa kepala ruangan memiliki persepsi yang sangat positif terhadap pengembangan panduan perawat sehat. Hasil survei tersebut didukung oleh pernyataan Kepala Bidang Pelayanan Keperawatan dan Ketua Komite Keperawatan yang menjelaskan bahwa pengembangan panduan perawat sehat sangat mendesak kebutuhannya dan perlu segera dimiliki panduan perawat sehat bagi staf keperawatan. Perawat mempunyai peran penting dalam mempromosikan kesehatan orang lain, namun penelitian menunjukkan bahwa banyak yang tidak memasukkan perilaku sehat ke dalam kehidupan mereka sendiri. Perawat perlu mempraktikkan perawatan dirinya sendiri untuk meningkatkan kesehatan dan kebugaran pribadi yang dapat berkontribusi pada kepuasan yang lebih besar baik dalam pekerjaan dan kehidupan pribadi (Rose \& Williams, 2015). Perawat sehat adalah perawat yang fokus secara aktif pada penciptaan dan penjagaan keseimbangan dan sinergi kesejahteraan fisik, intelektual, emosional, sosial, spiritual, personal dan professional (American Nurses Association, 2017).

Paradigma pelayanan kesehatan berpusat pada person/pasien dan ditujukan pada pelayanan yang aman. Seluruh tim kesehatan mempunyai peran dan fungsi yang berkolaborasi dalam mewujudkan pelayanan asuhan yang aman dan nyaman. Keperawatan sebagai bagian integral dari tim kesehatan mempunyai kontribusi besar dalam memberikan asuhan keperawatan. Selama 24 jam perawat memberikan asuhan keperawatan sehingga diperlukan suatu pelayanan dan asuhan keperawatan yang professional (Komisi Akreditasi Rumah Sakit, 2018).

Perawat sesuai dengan peran dan fungsinya saat memberikan asuhan keperawatan bukan hanya berdasarkan kompetensi dan kewenangan klinis yang dimiliki, namun diperlukan kondisi kesehatan yang mumpuni untuk menunjang tugas yang diberikan oleh organisasi rumah sakit. Perawat memiliki pengetahuan tentang pentingnya aktivitas yang meningkatkan kesehatan seperti makan sehat, aktivitas fisik, manajemen stres, kebersihan tidur dan menjaga hubungan yang sehat. Namun, pengetahuan ini tidak diterjemahkan ke dalam perawatan diri perawat itu sendiri. Perawat mungkin tidak mengikuti pedoman yang direkomendasikan untuk aktivitas fisik dan nutrisi yang tepat. Jam kerja yang panjang, beban kerja yang berlebihan dan kerja shift yang terkait dengan praktik keperawatan dapat membuat stres dan berkontribusi pada ketidakpuasan kerja, kelelahan dan konsekuensi kesehatan seperti obesitas dan gangguan tidur (Ross et al., 2017).

Saat ini rumah sakit sudah memiliki program kesehatan pegawai yaitu senam kesehatan jasmani yang rutin dilaksanakan setiap hari Jum'at, namun belum dapat diikuti staf keperawatan karena keterbatasan waktu. Standar akreditasi Joint Commission International edisi 7 pada bab Staff Qualification and Education (SQE 8) menyatakan bahwa rumah sakit menyediakan program kesehatan dan keselamatan staf terkait kesehatan fisik dan mental (Keiler et al., 2021). Pasal 8 menyatakan bahwa program kesehatan dan keselamatan staf rumah sakit penting bagi pemeliharaan 
kesehatan fisik dan mental, kepuasan, produktivitas serta kondisi kerja yang aman bagi staf. Pembuat kebijakan, petugas kesehatan masyarakat dan penyedia layanan kesehatan harus memahami peran penting sebagai pemimpin dalam mempromosikan kegiatan yang sehat untuk orang lanjut usia (Komatsu et al., 2020).

Pengembangan draft panduan perawat sehat sebagai langkah awal optimalisasi kesehatan staf keperawatan di rumah sakit sangat penting oleh perawat manajer yang merasakan kebutuhan untuk berubah, terdapat hubungan saling membantu dengan agens pengubah, mengidentifikasi bersama, mengumpulkan data, mengkaji sumber daya untuk perubahan, yang selanjutnya akan berkembang untuk modifikasi perubahan aktif. Apabila sudah terbentuk perubahan aktif, tahap selanjutnya menstabilkan perubahan dan hubungan saling membantu untuk tercapainya peningkatan kesehatan staf keperawatan di RS X, teori perubahan (Marquis \& Huston, 2017).

Pelaksanaan pengembangan panduan perawat sehat menggunakan kerangka POSAC, yaitu fungsi manajemen keperawatan dari mulai perencanaan, pengorganisasian, ketenagaan, pengarahan dan pengendalian. Pada fungsi perencanaan, implementasi yang dilakukan adalah penyusunan draft pengembangan panduan perawat sehat sebagai langkah awal optimalisasi kesehatan staf keperawatan melibatkan kepala seksi rawat inap bidang pelayanan keperawatan, ketua komite keperawatan, kepala sub kredensial komite keperawatan dan penanggung jawab mutu bidang pelayanan keperawatan.

Penyusunan draft pengembangan panduan perawat sehat sebagai langkah awal optimalisasi kesehatan staf keperawatan mendapat arahan dan usulan perbaikan draft agar mampu laksana di rumah sakit. Implementasi pengorganisasian mengusulkan pembentukan time table kegiatan penyusunan draft pengembangan panduan healthy nurse sebagai langkah awal optimalisasi kesehatan staf keperawatan mendapat arahan dan usulan perbaikan draft. Implementasi fungsi ketenagaan yaitu melibatkan anggota tim penyusun draft pengembangan panduan perawat sehat sebagai langkah awal optimalisasi kesehatan staf keperawatan. Implementasi fungsi pengarahan yaitu melakukan konsultasi dengan pembimbing akademik dan pembimbing klinik untuk mendapatkan arahan penyempurnaan draft pengembangan panduan perawat sehat sebagai langkah awal optimalisasi kesehatan staf keperawatan. Selanjutnya fungsi pengendalian yaitu membuat evaluasi dan tindak lanjut penyusunan draft pengembangan panduan perawat sehat sebagai salah satu langkah awal optimalisasi kesehatan staf keperawatan.

Perubahan terencana untuk manajemen fasilitas dan keselamatan disebutkan bahwa Rumah Sakit mempunyai program pengelolaan keselamatan dan keamanan melalui penyediaan fasilitas fisik dan menciptakan lingkungan yang aman bagi pasien, keluarga, pengunjung dan staf (KARS, 2018). Standar akreditasi Facility Management and Safety (FMS) JCI edisi 7 disampaikan bahwa rumah sakit mengembangkan dan menerapkan program untuk menyediakan lingkungan yang aman bagi pasien, keluarga, staf dan pengunjung (Keiler et al., 2021). Berdasarkan pernyataan tersebut dijelaskan bahwa fasilitas staf keperawatan dalam memberikan asuhan keperawatan dilindungi oleh standar akreditasi nasional rumah sakit maupun internasional.

Kebutuhan peningkatan kesehatan staf keperawatan ditunjang oleh penelitian Thomas (2020) bahwa organisasi mendukung perpanjangan waktu kafetaria untuk memberi kesempatan semua shift mendapatkan makanan berkualitas dan pemesanan pilihan makanan yang lebih sehat untuk menunjang kesehatan di masa depan. Perawat bertanggung jawab untuk mengoptimalkan kesehatan dan kemampuan pasien, 
mencegah penyakit dan cedera, memfasilitasi penyembuhan dan mengurangi penderitaan (American Nurses Association, 2017). Sepuluh risiko bahaya kerja perawat yang signifikan adalah: stres di tempat kerja (79\%), mengangkat atau mengubah posisi benda berat termasuk pasien (39\%), berdiri lama (37\%), luka tertusuk jarum dan benda tajam lainnya (35\%), kelelahan yang berlebihan mempengaruhi kualitas hidup (32\%), patogen yang ditularkan melalui darah seperti HIV atau hepatitis $(31 \%)$, agen penyakit menular seperti penyakit TBC (28\%), risiko tidak aman (7\%), risiko tergelincir, tersandung dan jatuh (26\%) dan risiko gangguan pendengaran seperti kebisingan (19\%) (American Nurses Association, 2019). Perawat dapat mengoptimalkan kesehatan dirinya sesuai dengan pengetahuan yang dimiliki.

Manajer harus menciptakan lingkungan kerja yang dapat memenuhi, baik kebutuhan organisasi maupun individu dalam hal ini staf keperawatan untuk mempertahankan produktivitas sekaligus mendorong kepuasan kerja staf (Marquis \& Huston, 2017). Diperlukan pengambilan keputusan oleh para manajer keperawatan yang mempunyai posisi dalam peran dan fungsinya untuk meningkatkan kesehatan staf keperawatan dengan membuat suatu panduan sebagai program peningkatan kesehatan staf keperawatan. Panduan tersebut mampu diimplementasikan pada pelayanan rumah sakit. Dengan disusunnya draft pengembangan panduan perawat sehat sebagai langkah awal optimalisasi kesehatan staf keperawatan dapat menjadi acuan bagi staf keperawatan untuk meningkatkan kesehatan sesuai dengan kemampuan dan kompetensi yang dimiliki. Salah satu program kesehatan dengan pemilihan makanan sehat dapat membantu mengelola stres, menjaga berat badan pada titik yang sehat dan tingkat energy untuk pentingnya gizi bagi kesehatan staf keperawatan yang baik, lebih sering perawat yang memberikan penilaian gizi dan/atau pendidikan kesehatan kepada pasien, tapi juga berfungsi sebagai panutan (Haidari et al., 2018).

\section{SIMPULAN}

Implementasi penyusunan draft panduan perawat sehat di rumah sakit $\mathrm{X}$ di Jakarta dapat dilaksanakan sesuai dengan yang direncanakan. Keterlibatan tim serta dukungan dari Bidang Pelayanan Keperawatan dan Komite Keperawatan sangat diperlukan sehingga pengembangan panduan perawat sehat dapat dilaksanakan. Perawat manajer dapat memberikan pemahaman kepada staf keperawatan tentang diperlukannya pelaksanaan draft panduan perawat sehat sebagai upaya optimalisasi kesehatan staf keperawatan.

Draft panduan perawat sehat dapat dijadikan sebagai salah satu kebijakan yang berlaku di Rumah Sakit dengan pemantauan dan dilakukan evaluasi secara berkesinambungan untuk penyempurnaan.

\section{SARAN}

Implementasi draft panduan perawat sehat di rumah sakit $\mathrm{X}$ di Jakarta perlu mendapat dukungan penuh dari pimpinan rumah sakit untuk meningkatkan kesehatan staf keperawatan. Pimpinan rumah sakit perlu segera mengesahkan dokumen panduan perawat sehat yang diusulkan oleh Bidang Pelayanan Keperawatan. Bidang Pelayanan Keperawatan perlu segera melakukan sosialisasi dan upaya-upaya penyesuaian panduan perawat sehat untuk dilaksanakan. Plan of Action yang telah disusun dan disepakati hendaknya dilanjutkan oleh rumah sakit untuk ditindaklanjuti dan dilaksanakan. 


\section{DAFTAR PUSTAKA}

American Nurses Association. (2017). American Nurses Association Health Risk Appraisal: Executive Summary. http://www.nursingworld.org/HRA-executivesummary

American Nurses Association. (2019). Healthy Nurse Healthy Nation: Year Two Highlights 2018-2019. https://www.healthynursehealthynation.org/globalassets/all-images-view-withmedia/about/2019-hnhn_highlights.pdf

Bak, M. A. R., Hoyle, L. P., Mahoney, C., \& Kyle, R. G. (2020). Strategies to Promote Nurses' Health: A Qualitative Study with Student Nurses. Nurse Education in Practice, 48, 1-11. https://doi.org/10.1016/j.nepr.2020.102860

Croke, L. (2020). Public Health Emergencies Underscore the Importance of Nurse Well-Being. AORN Journal, 112(2), 5. https://doi.org/10.1002/aorn.13152

Darch, J., Baillie, L., \& Gillison, F. (2019). Preparing Student Nurses to Be Healthy Role Models: A Qualitative Study. Nurse Education in Practice, 40, 1-7. https://doi.org/10.1016/j.nepr.2019.102630

Fletcher, G. F., Landolfo, C., Niebauer, J., Ozemek, C., Arena, R., \& Lavie, C. J. (2018). Reprint of: Promoting Physical Activity and Exercise: JACC Health Promotion Series. Journal of the American College of Cardiology, 72(23), 30533070. https://doi.org/10.1016/j.jacc.2018.10.025

Gartrell, K., Han, K., Trinkoff, A., \& Cho, H. (2020). Three-Factor Structure of the Ehealth Literacy Scale and Its Relationship with Nurses' Health-Promoting Behaviours and Performance Quality. Journal of Advanced Nursing, 76(10), 2522-2530. https://doi.org/10.1111/jan.14490

Haidari, F., Mohammadshahi, M., Haghighizadeh, M. H., \& Khoramabadi, Z. (2018). Relationship between Quality of Life and Healthy Eating Index Among Healthy Nurses in Ahvaz, Southwest Iran. Research Journal of Pharmacy and Technology 11(6), 2183-2190. https://doi.org/10.5958/0974-360X.2018.00404.3

Horton Dias, C., \& Dawson, R. M. (2020). Hospital and Shift Work Influences on Nurses' Dietary Behaviors: A Qualitative Study. Workplace Health and Safety, 68(8), 374-383. https://doi.org/10.1177/2165079919890351

Keiler, R., Jorgenson, C., Fry, H. M., Chopp Hinckley, C., Chien, L., Hofmann, P., President, L., Kohli, M., \& Chair, F. (2021). Joint Commission International Accreditation Standards for Hospitals Including Standards for Academic Medical Center Hospitals (7th ed.). https://www.jointcommissioninternational.org

Komatsu, H., Yagasaki, K., Oguma, Y., Saito, Y., \& Komatsu, Y. (2020). The Role and Attitude of Senior Leaders in Promoting Group-Based Community Physical Activity: A Qualitative Study. BMC Geriatrics, 20(1), 1-10. https://doi.org/10.1186/s12877-020-01795-2

Komisi Akreditasi Rumah Sakit. (2018). Instrumen Survey Standar Nasional Akreditasi Rumah Sakit (SNARS) Edisi 1. Jakarta: KARS

Marquis, B. L., \& Huston, C. J. (2017). Leadership Roles and Management Functions in Nursing: Theory and Application (9th ed.). http://sbmu.ac.ir/uploads/marquis\%20leadership\%20roles\%20and\%20\%20\%20m anagement $\% 20$ functions $\% 20$ in $\% 20$ nursing $\% 20$ theory $\% 20$ and $\% 20$ application $\% 2$ 02017.pdf

McNamara, S. A. (2020). Healthy Nurses Can Inspire a Nation. AORN Journal, 111(1), 5-7. https://doi.org/10.1002/aorn.12912 
Phillips, A. (2019). Effective Approaches to Health Promotion in Nursing Practice. Nursing Standard (Royal College of Nursing (Great Britain) : 1987), 34(4), 4350. https://doi.org/10.7748/ns.2019.e11312

Rose, T., \& Williams, D. J. (2015). Nurse leadership: The Importance of Balancing Work with Leisure. Nurse Leader, 13(3), 60-62. https://doi.org/10.1016/j.mnl.2014.08.004

Ross, A., Bevans, M., Brooks, A. T., Gibbons, S., \& Wallen, G. R. (2017). Nurses and Health-Promoting Behaviors: Knowledge May Not Translate into Self-Care. AORN Journal, 105(3), 267-275. https://doi.org/10.1016/j.aorn.2016.12.018

Thomas, B. (2020). The Healthy Nurse: Identifying Barriers to Healthy Eating at Work. Current Developments in Nutrition, 4(2), 286-286. https://doi.org/10.1093/cdn/nzaa043_137

Thompson, B. J. (2019). Does Work-Induced Fatigue Accumulate Across Three Compressed 12 Hour Shifts in Hospital Nurses and Aides? PLoS ONE, 14(2), 116. https://doi.org/10.1371/journal.pone.0211715

Uchendu, C., Windle, R., \& Blake, H. (2020). Perceived Facilitators and Barriers to Nigerian Nurses' Engagement in Health Promoting Behaviors: A SocioEcological Model Approach. International Journal of Environmental Research and Public Health, 17(4), 1-20. https://dx.doi.org/10.3390/ijerph17041314

Wijaya, D., \& Damayanti, N. A. (2018). Healthy Nurses for a Quality Health Care Service: A Literature Review. Indian Journal of Public Health Research and Development, 9(11), 1762-1766. https://doi.org/10.5958/0976-5506.2018.01699.6

Woudberg, N. J., Mendham, A. E., Katz, A. A., Goedecke, J. H., \& Lecour, S. (2018). Exercise Intervention Alters HDL Subclass Distribution and Function in Obese Women. Lipids in Health and Disease, 17(1), 1-13. https://doi.org/10.1186/s12944-018-0879-1 